\title{
Study on Genetic Variability and Heritability in F5 Segregating Generation for Yield and Its Compenents in Yardlong Bean
}

\author{
Florentina Kusmiyati *, Syaiful Anwar, and Bagus Herwibawa
}

\author{
Faculty of Animal and Agriculture Sciences, University of Diponegoro \\ *Corresponding author. Email: fkusmiyati@live.undip.ac.id
}

\begin{abstract}
Yardlong bean is one of the important vegetable crops in Indonesia. Immature pod of yardlong bean has various colour such as green, whitish green, red and purple. Artificial cross was done between purple and whitish green pod to get F1. First filial (F1) were advanced to F5 segregating generations for variability and heritability. The research objective was to estimate variability and heritability in F5 populations. There were nine genotypes of F5 population. Characters measured were number of leaf, pod length, number of pod, number of seed per pod, number of seed per plant and weight of 100 seeds. The results showed that significance difference observed among genotypes for all characters. The phenotypic variance $\left(\sigma 2_{\mathrm{p}}\right)$ and phenotypic coefficient of variation (PCV) were higher than corresponding genotypic variance $(\sigma 2 \mathrm{~g})$ and genotypic coefficient of variation $(\mathrm{GCV})$ for most of the characters. High heritability were obtained for number of leaf, number of pod and number of seed/plant. Pod length, number of seed/pod and weight of 100 seeds had moderate heritability. Number of seed per plant had high heritablity and high genetic advance
\end{abstract}

Keywords: Genotypic Coefficients of Variation, Purple pod, Whitish Pod

\section{INTRODUCTION}

Yardlong bean is one of the important vegetable crops in Indonesia and many other regions including Southeast Asia, West Africa and South China. Harvested area of yardlong bean in Indonesia is 53.405 ha, with production 370.225 ton and yield per hectare 6.93 ton/ha in 2018 [1]. In Indonesia, harvested area and production of yardlong bean is decreasing year after year. In 2020, production of yardlong bean was 359.158 ton[2]

(https://www.bps.go.id/indicator/55/61/1/produksi-

tanaman-sayuran.html). Yardlong bean is quite sensitive to adverse environmental condition and responsive to various insect and diseases. Therefore, it is advantageous to develop a new better adjustable and productive variety.

The goal of yardlong bean breeding is to improve yield, improve quality and resistance to pests and diseases. One of the concern quality in yardlong bean is nutritive value such as anthocyanins that is related to human health. Various colour of yardlong bean immature pod has different nutritive value. Immature pod of yardlong bean has various colour such as green, whitish green, red and purple. Anthocyanins are found in red and purple immature pods [3]. Green immature pods has chlorophyll which also has functions as an antioxidant [4].

Genetic variability is needed before determining plant breeding method and also selection methods including the right time for selection. In addition, it is also necessary to calculate heritability of characters that will be target of selection. Heritability is the amount of genetic variability which may be transmitted to the progeny. Heritability may also described as variation proportion in a progeny which derives from genetics factors of total variation. Characters that are so highly influenced by environmental condition will have lower heritability. Characters that are not highly influenced by environmental condition will have higher heritability.

Selection for characters with high heritability are usually effective in early generations [5]. Evaluation of 41 diverse genotypes of yardlong bean in Hyderabad showed high heritability for pod length, number of pod, 
number of seed/pod and weight of 100 seeds were $99 \%$, $83 \%, 62 \%$ and $96 \%$, respectively [6]. Immature pod of yardlong bean has various colour such as green, whitish green, red and purple. Crossing between two different colour is expected to improve variability. The research objective was to estimate variability and heritability of yardlong bean in $\mathrm{F} 5$ populations.

\section{MATERIALS AND METHODS}

The research was done at Agrotechnopark, Tembalang - Semarang, Central Java, Indonesia. Artificial cross was done between purple and whitish green immature pod to get F1. First filial (F1) were advanced to F5. There were nine genotypes of F5 population. The genotypes were sown using Randomized Block Design (RBD) with three replication at Agrotechnopark, Semarang, Central Java - Indonesia. Seeds were sown with of spacing $50 \mathrm{~cm}$ between plant in the same genotypes. The distance between genotypes was $75 \mathrm{~cm}$. There were 20 plants for each genotypes.

Soil tillage was done before planting. Seeds were planted with $50 \mathrm{~cm} \times 50 \mathrm{~cm}$ at each plot. Manure was applied one week before planting. Fertilizer dosage were $100 \mathrm{~kg} / \mathrm{ha} \mathrm{N}, 200 \mathrm{~kg} / \mathrm{ha} \mathrm{P} 2 \mathrm{O} 5$ and $100 \mathrm{~kg} / \mathrm{ha} \mathrm{K} 2 \mathrm{O}$. Disease and pest were controlled during growing period. Characters measured were number of leaf, pod length, umber of pod, number of seed per pod, number of seed per plant and weight of 100 seeds. Number of leaf was observed when $100 \%$ of plants started flowering. Pod length was measured at fresh pod. Number of seed per pod, number of seed per plant and weight of 100 seeds was observed at dry pod.

The data was subjected for analysis of variance to calculate mean square of genotypes (MSg) [7]. Means of the genotypes were used to calculate genetic parameters such as phenotypic variance $(\sigma 2 \mathrm{p})$, genotypic variance $(\sigma 2 \mathrm{~g})$, environmental variance $(\sigma 2 \mathrm{e})$, phenotypic coeffiecient of variation (PCV), genotypic coefficient of variation (GCV), environmental coefficients of variation (ECV), percentage coefficient of variation $(\% \mathrm{CV})$ and genetic advance to show variability among genotypes. The phenotypic variation for each characters was separated into genetic and nongenetic factors [8]

$\sigma 2 \mathrm{e}=\mathrm{MSe}$

$\sigma 2 \mathrm{~g}=(\mathrm{MSg}-\mathrm{MSe}) / \mathrm{r}$

$\sigma 2 p=\sigma 2 g+\sigma 2 \mathrm{e}$ respectively. MSg, MSe and $\mathrm{r}$ are the mean square of genotypes, mean squares of error and number of blocks,

$$
\begin{gathered}
P C V=\frac{\sqrt{\sigma_{p}^{2}}}{\bar{X}} \times 100 \\
G C V=\frac{\sqrt{\sigma_{s}^{2}}}{\bar{X}} \times 100 \\
q_{C V}=\frac{\sqrt{\sqrt{W_{s}}}}{\bar{X}} \times 100 \\
E C V=\frac{\sqrt{\sigma_{c}^{2}}}{\bar{X}} \times 100
\end{gathered}
$$

$\bar{X}$ is the mean for each measured trait. Broad sense heritability (H2bs) is expressed as the percentage of the ratio between genotypic variance $(\sigma 2 \mathrm{~g})$ and phenotypic variance $(\sigma 2 p)[9]$

$$
\mathrm{H} 2 \mathrm{bs}=\sigma 2 \mathrm{~g} / \sigma 2 \mathrm{p}
$$

The heritability estimate was categorized as follows ( Syukur, 2009) [10] :

$$
\begin{aligned}
& 0-19 \%=\text { Low }, 20-50 \%=\text { Moderate and } \\
& >50 \%=\text { high }
\end{aligned}
$$

Genetic advance (GA) was calculated [11]

$\mathrm{GA}=\mathrm{K} \times \mathrm{Sp} \times \mathrm{H} 2 \mathrm{bs}$

where $\mathrm{K}$ is a constant (2.06) at $5 \%$ selection pressure, $S p$ is the phenotypic standar deviation $\left(\sqrt{ }_{\sigma} 2\right)$ and $\mathrm{H} 2 \mathrm{bs}$ is the heritability ratio.

\section{RESULTS AND DISCUSSIONS}

\subsection{Genetic Variability}

Variability of genetic in breeding materials is prerequisite for a successful plant breeding program. Understanding variability magnitude in plant species is crucial because it provides the base for selection. The mean squares and genetic parameters for some quantitative character in F5 of yardlong bean are displayed in Table 1. The Anova showed a sigificant (P $<0.05)$ variation for all characters in the genotypes. The significance difference observed among genotypes for all characters suggested the existence of inherent genetic variability. Genetic variation among genotypes at this study is needed to successfully select and manage yield improvement program [12] .

where $\sigma 2 \mathrm{e}, \sigma 2 \mathrm{~g}$ and $\sigma 2 \mathrm{p}$ are environmental variance, genotypic variance adn phenotypic variance, 
Table 1. Mean Square and Genetic Parameters for Some Quantitative Character in F5 Population Of Yardlong Bean

\begin{tabular}{|c|c|c|c|c|c|c|c|c|c|}
\hline Character & Mean & $\sigma 2 p$ & $\sigma 2 g$ & $\sigma 2 e$ & $\begin{array}{c}\text { PCV } \\
(\%)\end{array}$ & $\begin{array}{c}\text { GCV } \\
(\%)\end{array}$ & $\begin{array}{c}\text { ECV } \\
(\%)\end{array}$ & $\begin{array}{l}\text { CV } \\
(\%)\end{array}$ & $\mathrm{MSg}$ \\
\hline Number of leaf/plant & 31.2 & 43.6 & 56.2 & 17.4 & 27.5 & 24.1 & 13.4 & 13.4 & $186.0^{*}$ \\
\hline Pod length (cm) & 44.2 & 47.6 & 22.3 & 25.3 & 15.5 & 10.7 & 11.4 & 11.4 & $92.2^{*}$ \\
\hline Number of pod/plant & 21.8 & 30.5 & 20.9 & 9.5 & 25.3 & 21.0 & 14.2 & 14.2 & $72.3^{*}$ \\
\hline Number of seed/pod & 13.8 & 4.2 & 1.9 & 2.3 & 14.8 & 10.0 & 10.8 & 10.8 & $8.0^{*}$ \\
\hline Number of seed/plant & 225.4 & 3377.3 & 1943.4 & 1433.9 & 25.8 & 19.5 & 16.8 & 16.8 & $7264.0^{*}$ \\
\hline Weight of 100 seeds $(\mathrm{g})$ & 16.5 & 0.8 & 0.3 & 0.5 & 5.3 & 3.3 & 4.2 & 4.2 & $1.3^{*}$ \\
\hline
\end{tabular}

Coefficient of variation (\% CV) compares the relative amount of variability in the population. The highest coefficient of variation was obtained by number of pod per plant. This results imply that number of pod per plant had higher amount of exploitable genetic variability and has greater potential for favourable advance in selecting this character compared to others The lowest $\% \mathrm{CV}$ was recorded for weight of 100 seeds. This is indicated that weight of 100 seeds has low exploitable genetic varaibility and as a result, has less potential for favourable advance in selecting when compared to other characters.

The phenotypic variance $\left(\sigma^{2} p\right)$ and phenotypic coefficient of variation (PCV) were higher than corresponding genotypic variance $\left(\sigma_{\mathrm{g}}^{2}\right)$ and genotypic coefficient of variation (GCV) for most of the characters. This is indicated the presence of environmental effect upon the concerned characters. The maximum phenotypic coefficient of variation (PVC) was observed for number of leaf, number of pod and number of seed per plant. This results indicated wider genetic variability for these traits. It is also suggested the scope for these characters improvement through selection. High PCV for number of pod per plant was earlier reported by several researcher in yardlong bean [6] [13]. High PCV indicates the existence of a greater scope of selection for the character being considered which depends on the amount of variability present [14].

The genotypic coefficient of variation (GCV) provides a measure of genetic variability that exists in different quantitative traits. The highest genotypic coefficient of variation (GVC) was observed for number of leaf. The lowest GCV was recorded for weight of 100 seeds. High GCV indicates the presence of exploitable genetic variability for the character, which can facilitate selection [15]. Estimates for PCV were higher than those for GCV, but the estimates of PCV and GCV were close. This was implied that genotype contributed more than environment in the expression of these characters and selection based on phenotypic values is feasible.

\subsection{Heritability Estimates}

Estimates of heritability give an observation into the extent of genetic control to pointed a particular character and phenotypic reliability in predicting its breeding value [12]. High heritability implies less influence of environmental in the observed variation [16]. Broad sense heritability (H2bs) only implies whether or not there is sufficient genetic variation in a population, which indicates whether or not a population will respond to selection pressure [17].

Heritability values of some character in this research range between $38.4 \%-76.4 \%$ (Table 2).. Number of leaf, number of pod and number of seed per plant in F5 population of yardlong bean had high heritability. Pod length, number of seed/pod and weight of 100 seeds had moderate heritability (Table 2). Several studies on yardlong bean showed that broad sense heritability was high on number of pod per plant [18] [19] [20] [21], number of seed per plant [21]. Seed number per pod had moderate broad sense heritability [20].

It is necessary to estimate heritability value of certain characters to predict whether the inheritance of certain character is influenced by genetic or environmental factors. High heritability (more than 50 $\%$ ) indicates that influence of genetics factors is greater on appearance of phenotype than influence of environment factors. High heritability value play a role in increasing the effectiveness of selection [10]. Based on the heritability of yardlong bean in F5, characters that can be used as selection criteria in this study is number of leaf, number of pod and number of seed per plant.

Heritability accomponied by genetic advance is more useful than heritability alone to access a more effective character selection [17]. In the present study, high $\mathrm{H} 2 \mathrm{bs}$ were recorded for number of leaf, number of pod and number of seed per plant. Number of leaf and number of pod had low genetic advance (GA). The high heritability observed of those two characters might be because of the favourable influence of the 
environmental rather than the genotype. Simple selection will therefore not be worthwhile. However, these characters could be improved by developing hybrid varieties or isolating transgressive segregants in heterosis. Number of seed per plant had high heritablity and high genetic advance. This is indicated that it was governed by additive gene action and therefore provides the most effective condition for selection [12]. The highest GA for number of seed per plant suggest that the variation in this character was mainly genetic with less environmental influence coupled with the prevalance of additive gene action in their inheritance [22].

Table 2. Heritability anf Genetic Advanvce (GA) for in F5 Population of Yardlong Bean

\begin{tabular}{|l|l|l|}
\hline Character & Heritability (\%) & GA (\%) \\
\hline Number of leaf/plant & 76.4 & 13.4 \\
\hline Pod length (cm) & 46.9 & 6.7 \\
\hline Number of pod/plant & 68.7 & 7.8 \\
\hline Number of seed/pod & 46.1 & 1.9 \\
\hline Number of seed/plant & 57.5 & 69.4 \\
\hline Weight of 100 seeds (g) & 38.4 & 0.7 \\
\hline
\end{tabular}

\section{CONCLUSION}

The genetic variation among genotypes at this study is needed to successfully select and manage yield improvement program. Number of seed per plant had high heritablity and high genetic advance therefore provides the most effective condition for selection

\section{AUTHORS' CONTRIBUTIONS}

Florentina Kusmiyati and Bagus Herwibawa conceived of the presented idea. Florentina Kusmiyati performed the measurement. Syaiful Anwar and Bagus Herwibawa were involved in planning and supervised the research in the field. Syaiful Anwar performed the computation and verified analytical methods. All authors discussed the results and contributed to the final manuscript.

\section{ACKNOWLEDGMENTS}

The authors are grateful to Directorate of Research and Community Service, Ministry of Research and Technology/National Research and Innovation Agency for financial support through Fundamental Research

\section{REFERENCES}

[1]. BPS-Statistics Indonesia. Statistics of Seasonal Vegetables and Fruits Plants Indonesia 2018, BPS-Statistics Indonesia, 2019
[2] https://www.bps.go.id/indicator/55/61/1/produksitanaman-sayuran.html

[3] T.J. Ha, M.H. Lee, C.H. Park, S.B. Pae, K.B. Shim, J.M. Ko, S.O. Shin, I.Y. Baek and K.Y. Park. Identification and characterization of anthocyanins in Yard-Long Beans (Vignaunguiculata ssp. sesquipedalis L) by high- performance liquid chromatography with diode array detection and electrospray ionization/ mass spectrometry, J. Agric. And Food Chem, 58, 2571- 2576, 2010.

[4] N. Nurdin, C.M. Kusharto, I. Tanziha , M. Januati, Kandungan klorofil berbagai jenis daun tanaman dan Cu-turunan klorofil serta karakteristik fisikokimianya, J. Gizi dan Pangan, 4(1):13-19, 2009, DOI: https://doi.org/10.25182/jgp.2009.4.1.13-19

[5] T. Sarutayophat, C. Nualsri, The efficiency of pedigree and single seed descent selections for yield improvement at generation 4 (F4) of two yardlong bean populations. Kasetsart J. (Nat. Sci.) $44: 343-352,2010$

[6] E. Rambabu, K.R. Reddy, V. Kamala, P. Saidaiah, S.R. Pandravada, Genetic variability and heritability for quality, yield and yield components in Yardlong bean (Vigna unguiculata (L.) Walp. ssp. sesquipedalis Verdc.), Green Farming, 7 (2) : $311-315,2016$

[7] R.G.D. Steel, J.H. Torrie, Principles and Procedures of Statistics. A biometrical approach. 2nd edition. McGraw-Hill, New York, USA, 1980

[8] J.R. Sharma, Statistical and biometrical techniques in plant breeding. 432 p. New Age International Limited Publishers, New Delhi, India, 1988

[9] C.O. Ene, P.E. Ogbonna, C.U. Agbo, U.P. Chukwudi, Studies of phenotypic and genotypic varaition in sixteen cucumber genotypes. Chilean J Agric. Res, 76 (3), 2016, DOI http://dx.doi.org/10.4067/S071858392016000300007

[10] M. Syukur, S. Sujiprihati, R. Yunianti, Teknik Pemuliaan Tanaman, Penebar Swadaya, 2015

[11] W.I. Fehr, Principles of Cultivar Development, Macmillan, 1987

[12] J. Ndukauba, G.E. Nwofia, P.I. Okocha, E.E. Enebong, Variability in Egusi-Melon genotypes (Citrullus lanatus [Thumb] Matsum and Nakai) in derived Savannah environment in Soutj-Eastern Nigeria, Int. J. Plant Res., 5 (1) : 19 - 26, DOI:10.5923/j.plant.20150501.04

[13] P.S. Resmi, V.A. Celine, M.A. Vahab, Genetic variability in yardlong bean (Vigna unguiculata 
subsp. Sesquipedalis (L.) Verdc.), Legume Res. 27(4) : $296-298,2012$

[14] A.S.M.M.R. Khan, M.Y. Kabir, M.M. Alam, Variability, correlation, path analysis of yield and yield component of pointed gourd. J. Agric. Rural Devel. 7(1-1): $93 \quad$ - 98, 2009, DOI:10.3329/jard.v7i1.4427

[15] Y.C. Yadav, S. Kumar, B. Bisen, S.K. Dixit, Genetic variabilty, heritability and genetic advance for some traits in cucumber. Indian J. Agric. Res. 8: $51-57,2009$

[16] M.H. Eid, Estimation of heritability and genetic advance of yield traits in wheat (Triticum aestivum L.) under drought condition. Int. J. Genet. Mol. Biol. 1 (7) : 115 - 120, 2009

[17] M.Z. Ullah, M.J. Hassan, A.Z.M.K.A. Chowdhury, A.I. Saki, A.H.M.A. Rahman, Genetic variability and correlation in exotic cucumber (Cucumis sativus) varieties. Bangladesh J. Plant Breed. Genet, 25 (1) : $17-23,2012$

[18] N. Savithiri, A. Beaulah, K.S. Thingalmaniyan, S. Rajeswari, R. Kumar, Study on genetic variability for yield and quality of different genotypes of yardlong bean (Vigna unguiculata sub sp. sesquipedalis (L.) Verd.). Int. J. Curr. Microbiol. App. Sci. 7 (9) : 3613 - 3617, 2018, Doi : https://doi.org/10.20546/ijcmas.2018.709.448

[19] D. Rout, G.S. Sahu, P. Tripathy, S.K. Dash, B. Pradhan, S. Das, Studies on genetic variability, heritability and genetic advance for vegetativ growth, flowering, pod and pod yield parameters in yardlong bean (Vigna unguiculata L. var. sesquipedalis), J. Pharmacognosy and Phytochemistry, 7(6) : $775-778,2018$

[20] P.P. Bhagavati, T.S.K.K.K. Patro, M.L.N. Reddy, N. Emmanuel, D.R.S. Suneetha, N.V. Prasad, Studies on genetic variability, heritability and genetic advance in yardlong bean (Vigna unguiculata (L.) walp. ssp. sesquipedalis verdc.), Int. J. Chem. Studies, 6 (4) : 1135 - 1138, 2018

[21] C. Vidya, K. Sunny, S.K. Oommen, K.V.Vijayaraghava, Genetic variability and heritability of yieldand related characters in yardlong bean. J. Trop. Agric. 40:11-13, 2002

[22] M. Tazeen, K. Nadia, N.N. Farzana, Heritability, phenotypic correlation and path coefficient studies for some agronomic characters in synthetic elite lines of wheat. J. Food Agric. Environ. 7 (3-4) : 278-282. 